\title{
An Attempt to Standardize Swarna Makshika - A Mineral Drug of Ayurveda
}

\author{
Research Article
}

\section{Prem Shankar Pandey ${ }^{1^{*}}$}

1. Department of Rasa Shastra and Bhaishajya Kalpana, Faculty of Ayurveda, Institute of Medical Sciences, Banaras Hindu University, Varanasi-221005, India

\begin{abstract}
Swarna Makshika(SM) is a brassy golden yellowish mineral with chemical composition of $\mathrm{CuFeS}_{2}$ (chalcopyrite). This deals with the mineralogical characterization of SM following the standards of classical as well as contemporary references. SM is widely used in therapeutics, in the form of Bhamsa to treat diseases such as Kasa (cough), Kushta (disease of skin), Pandu (anaemia), Prameha(diabetes), Jeernajwara (chronic fever), Rajyakshama (tuberculosis), Arsa (haemorraids) and various other diseases. It is thus necessary to validate and establish those properties on the basis of contemporary knowledge for the selection of genuine sample because raw drug standardization plays a vital role in assessing final drug for better therapeutic effects. For this study, the sample of SM was collected from Ayurvedic pharmacy, Banaras Hindu University and authenticated by the subject expert. The identification, physical verification, physical properties and mineralogical description of SM were conducted as mentioned in the Ayurvedic classic texts, Ayurvedic Pharmacopoea of India and Electron Probe Micro Analysis (EPMA) study. The results showed that SM is chalcopyrite (Copper and Iron disulphide) with metallic luster, brassy golden yellow, resembles a tetrahedron crystal habit, brittle tenacity and conchoidal fracture. All these physical properties of mineral chalcopyrite are very well match with the acceptable characteristics of SM as described in Ayurvedic classics.
\end{abstract}

Keywords: Swarna Makshika, Chalcopyrite, Mineral, Rasa Shastra, Maharasa.

\section{Introduction}

Standardisation is the burning topic in Ayurvedic drug industry today. It is a measurement for ensuring the quality and is used to describe all the measures which are taken during manufacturing process and quality control leading to a reproducible quality. Ayurvedic metallic preparations with herbal juice/fruits widely used for treatment of a variety of chronic diseases. Metals play an important role in human body, the deficiency of which leads to various disorders. A number of metals as essential elements are present in the human body in different concentrations and combinations at various sites and help the respective body tissues to perform their normal activities. The excess or deficiencies of metals may disturb the body metabolism. Hence, genuine metallic drugs play an important role in curing various diseases. Bhasmas, the Ayurvedic metallic formulation are the products of inorganic compounds of certain metals and minerals in a very fine powdered form. In the process of Bhasma preparation the metals/minerals gets converted into desired formulations which eliminates the toxicity of the metal and has the necessary medicinal activities (1). It is therefore necessary to standardize raw metals/ minerals through detailed study of various physicochemical and analytical evaluation. It will make

*Corresponding Author:

Prem Shankar Pandey,

Department of Rasa Shastra and Bhaishajya Kalpana,

Faculty of Ayurveda, Institute of Medical Sciences,

Banaras Hindu University, Varanasi-221005, India

Email:pspandey482@gmail.com sure the safety, effectiveness and acceptability of the products.

Swarna Makshika(SM), shining like gold, is a copper ore containing chalcopyrite $\left(\mathrm{CuFeS}_{2}\right)$ mineral. It was only in Samhita era, the use of SM started as medicine. It is used in the form of Bhasma with great therapeutic values. Rasaratnasamucchayakaara $\left(13^{\text {th }}\right.$ century) gave a detailed description of SM regarding its quality, shodhana, marana etc and grouped it under Maharasa Verg (2). The Rasajalnidhi Kaara $\left(20^{\text {th }}\right.$ Century) compiled almost all the description pertaining to SM about its occurrence, types, therapeutic properties, identification methods, physical properties, sodhana and marana procedures, from the available texts (3). The importance of SM was explained in the treatment of Kushta (disease of skin) and Pandu (anaemia) diseases (4). Further, it is widely used in the treatment of Kasa(cough), Sotha(inflammation), Prameha(diabetes), Jeernajwara(chronic fever), Rajyakshama(tuberculosis), Apsmara(epilepsy), Arsa (haemorrhoids), Krimi(worm infection), Rajahkrichra (scanty menstruation) etc (5). The mineral sources of SM are found mainly in Bihar, Jharkhand, Rajasthan, Tamilnadu, Karnataka, Madhya Pradesh and Sikkim in India.

The manufacturing process for preparing Bhasma plays an important role in collection of authentic sample of SM which influences the quality of the final product and is directly related to the therapeutic potential of a drug. The Ayurvedic Pharmacopoeia of India (6) emphasized preliminary studies together with Grahyaagrahy Lakshana (acceptable and non-acceptable properties) of raw substance to identify and selection of genuine sample so that active formulations may be 
prepared. Hence, the present study has been taken to assess the characterization of SM for its mineralogical characterization through Ayurvedic as well as modern methods.

\section{Materials and Methods}

The samples of the raw SM were collected from Ayurvedic pharmacy, Banaras Hindu University and authenticated by subject expert. The mineral was tested by studying its characters as explained in classical texts (7). The physical properties and mineralogical characterization were made for acceptability of genuine sample by adopting different methods.

The identification and physical verification of SM according to Grahya-Lakhana (acceptable properties) was conducted as mentioned in the Ayurvedic classical texts (8). The analysis of the physical properties of SM was done as per the mineralogical description mentioned in the Ayurvedic Pharmacopoeia of India (6). The Electron Probe Micro Analysis was carried out at the Department of Geology, Banaras Hindu University, Varanasi, on instrument Cameca-SXFive Electro micro probe. Any query regarding instrumental technique, procedure and methodology may be obtained by Professor N. V. Chatapathi Rao and Dr. Dinesh Pandit who helped for EPMA analysis.

\section{Results}

\section{Identification of SM as per Ayurvedic classics}

The procured sample of SM was identified and verified as per Ayurvedic classics (3, 7, 8). Observations are depicted in Table- 1 .

Table-1: Grahya Lakshana (acceptable properties of SM as per Ayurvedic classics)

\begin{tabular}{|l|l|l|}
\hline $\begin{array}{l}\text { Acceptable } \\
\text { Properties }\end{array}$ & Physical Properties & $\begin{array}{l}\text { Observ } \\
\text { ations }\end{array}$ \\
\hline $\begin{array}{l}\text { Swarna } \\
\text { Sannibham }\end{array}$ & $\begin{array}{l}\text { Golden color and } \\
\text { Luster }\end{array}$ & + \\
\hline Snigdha & Smooth & + \\
\hline Guru & Heaviness & + \\
\hline Nishkona & No angles & + \\
\hline $\begin{array}{l}\text { Kalimam } \\
\text { Vikirettattu } \\
\text { Kare } \\
\text { Ghrushtam }\end{array}$ & $\begin{array}{l}\text { Rubbed on hand, black } \\
\text { color appear on hand } \\
\text { or white paper }\end{array}$ & + \\
\hline $\begin{array}{l}\text { Rubbed on } \\
\text { stone, gives } \\
\text { gold color lines } \\
\text { on the stone }\end{array}$ & $\begin{array}{l}\text { Gives gold color lines } \\
\text { on the stone }\end{array}$ & + \\
\hline
\end{tabular}

\section{Identification of physical properties of SM}

The physical characterization was carried out as per Ayurvedic Pharmacopoeia of India [6]. The mineralogical details of SM (chalcopyrite) were identified as per mineralogical description of chalcopyrite (9) as shown in Table-2, Figure-1. The EMPA study for the mineral chemistry and elemental assay of various phases of the studied sample is presented in Table-3, Figure-2.

Table-2 : The results of physical properties of SM (chalcopyrite)

\begin{tabular}{|c|c|}
\hline $\begin{array}{l}\text { Characterisation } \\
\text { Parameters } \\
\end{array}$ & Observations for SM \\
\hline Color & Brass-yellow \\
\hline Crystal habit & $\begin{array}{l}\text { Predominantly } \\
\text { disphenoid resembles a } \\
\text { tetrahedron crystal }\end{array}$ \\
\hline Nature of crystal & Crystalline and massive \\
\hline Crystal aggregate & Commonly \\
\hline Crystal system & $\begin{array}{c}\text { Tetragonal } \\
\text { scalenohedral }\end{array}$ \\
\hline Streak & Greenish-black \\
\hline Fracture & Conchoidal and brittle \\
\hline Cleavage & Indistinct \\
\hline Transmission & Opaque \\
\hline Tenacity & Brittle \\
\hline Luster & Metallic \\
\hline Magnetic & $\begin{array}{l}\text { Paramagnetic } \\
\text { characteristics }\end{array}$ \\
\hline Fizz test & Negative \\
\hline Flame color & Blue \\
\hline Roasting & $\begin{array}{l}\text { White fumes with garlic } \\
\text { odour }\end{array}$ \\
\hline Twinning & $\begin{array}{l}\text { Penetration and contact } \\
\text { twinning }\end{array}$ \\
\hline Fluorescence & No. fluorescence \\
\hline Conductivity & $\begin{array}{l}\text { Good conductor of heat } \\
\text { and electricity }\end{array}$ \\
\hline Moh's scale hardness & $3.5-4$ \\
\hline Specific gravity & $4.1-4.3$ \\
\hline $\begin{array}{l}\text { Heating open and closed } \\
\text { tube }\end{array}$ & $\begin{array}{l}\text { Profuse white fumes and } \\
\text { adhered to the test tube. }\end{array}$ \\
\hline Solubility & Soluble in $\mathrm{HNO}_{3}$ \\
\hline Rubbed on hand & Black color on hand \\
\hline Rubbed on stone & $\begin{array}{l}\text { Golden color lines on } \\
\text { stone }\end{array}$ \\
\hline Heating with charcoal & $\begin{array}{l}\text { Fuses to black mass, } \\
\text { strongly magnetic }\end{array}$ \\
\hline $\begin{array}{l}\text { Heated in oxygen } \\
\text { atmosphere }\end{array}$ & Smell of sulphurdioxide \\
\hline $\begin{array}{l}\text { Slight heating in air } \\
\text { atmosphere }\end{array}$ & $\begin{array}{l}\text { Sulphates of copper and } \\
\text { iron }\end{array}$ \\
\hline
\end{tabular}


Table-3: The chemical assay of mineral SM analysed by EPMA

\begin{tabular}{|c|c|c|c|c|c|c|c|c|c|c|c|c|c|}
\hline $\begin{array}{c}\text { Element } \\
\text { S.No. }\end{array}$ & $\mathbf{F e}$ & $\mathbf{C u}$ & $\mathbf{N i}$ & $\mathbf{P b}$ & $\mathbf{S n}$ & $\mathbf{S}$ & $\mathbf{A s}$ & $\mathbf{S b}$ & $\mathbf{B a}$ & $\mathbf{S i}$ & $\mathbf{A l}$ & $\mathbf{M g}$ & $\mathbf{N a}$ \\
\hline 1 & 46.98 & 0.17 & 0.31 & 0.40 & 0.51 & 52.89 & 0.22 & 0.19 & 0.25 & -0.03 & -0.07 & 0.02 & -0.20 \\
\hline 2 & 45.20 & 0.23 & 0.27 & 0.36 & 0.53 & 52.95 & 0.14 & 0.19 & 0.19 & -0.04 & -0.07 & 0.02 & -0.21 \\
\hline 3 & 45.04 & 0.20 & 0.27 & 0.22 & 0.53 & 52.76 & 0.14 & 0.16 & 0.13 & -0.02 & -0.05 & 0.02 & -0.23 \\
\hline 4 & 45.97 & 0.33 & 0.36 & 0.48 & 0.52 & 53.00 & 0.18 & 0.16 & 0.01 & -0.06 & -0.06 & 0.02 & -0.24 \\
\hline 5 & 46.20 & 0.43 & 0.33 & 0.35 & 0.50 & 53.07 & 0.19 & 0.19 & 0.22 & -0.05 & -0.06 & 0.02 & -0.20 \\
\hline 6 & 46.52 & 0.16 & 0.40 & 0.53 & 0.49 & 51.50 & 0.12 & 0.17 & 0.41 & -0.29 & -0.01 & 0.08 & -0.18 \\
\hline 7 & 45.52 & 0.20 & 0.41 & 0.40 & 0.45 & 52.32 & 0.15 & 0.16 & 0.37 & -0.04 & -0.06 & 0.03 & -0.23 \\
\hline 8 & 46.32 & 0.30 & 0.24 & 0.38 & 0.45 & 52.67 & 0.20 & 0.20 & 0.25 & -0.03 & -0.05 & 0.01 & 0.22 \\
\hline 9 & 45.69 & 0.14 & 0.31 & 0.35 & 0.47 & 52.72 & 0.20 & 0.12 & 0.28 & -0.03 & -0.07 & 0.02 & -0.22 \\
\hline 10 & 45.00 & 0.26 & 0.31 & 0.33 & 0.51 & 52.46 & 0.18 & 0.13 & 0.13 & -0.04 & -0.05 & 0.04 & -0.21 \\
\hline
\end{tabular}

Figure -1: Test conducted for physical properties verification of Swarna Makshika

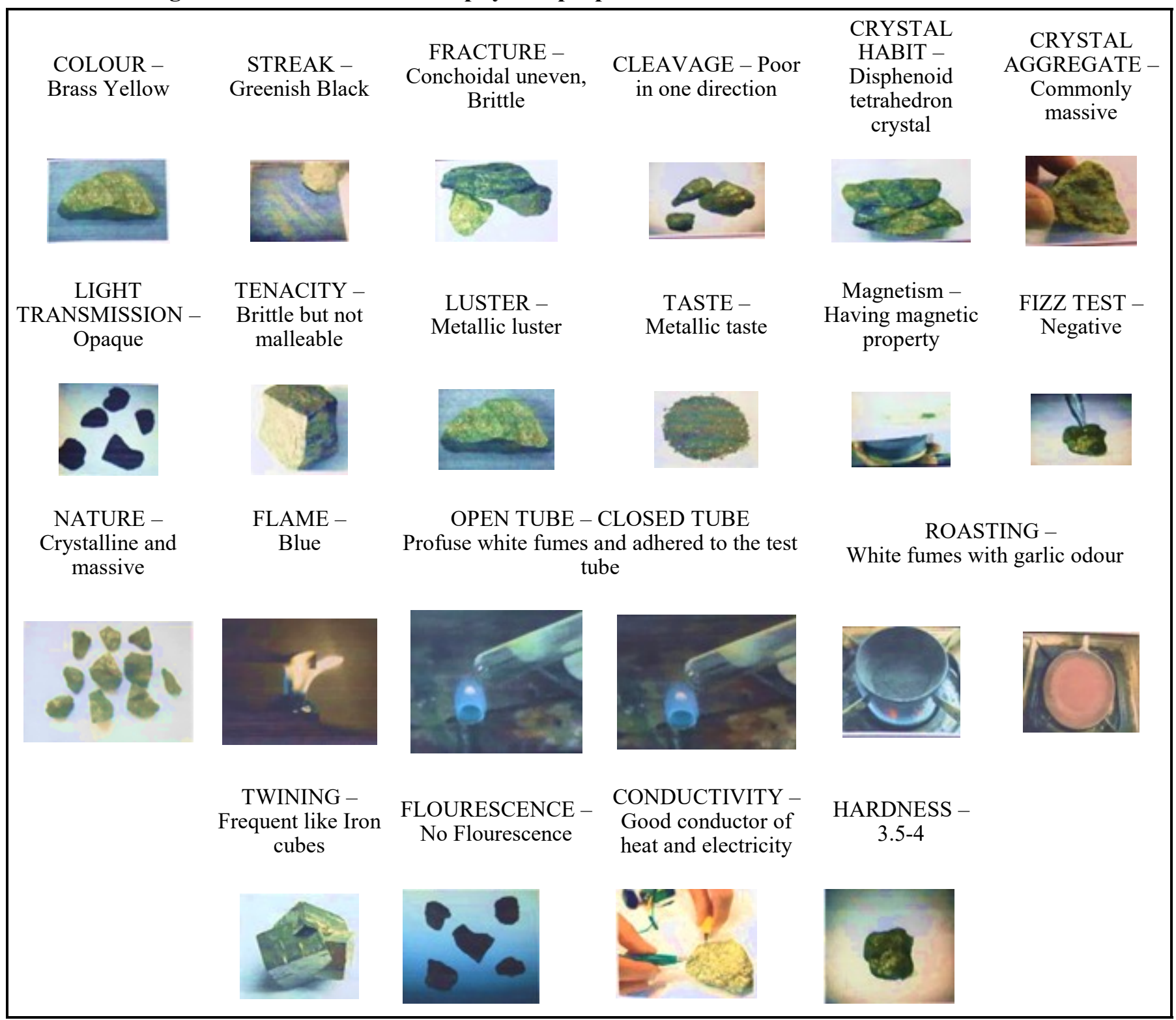


Figure - 2: Back scattered electron microscopy of mineral Swarna Makshika Electron Probe Micro Analysis (EPMA)

EPMA OF SWARNA MAKSHIK

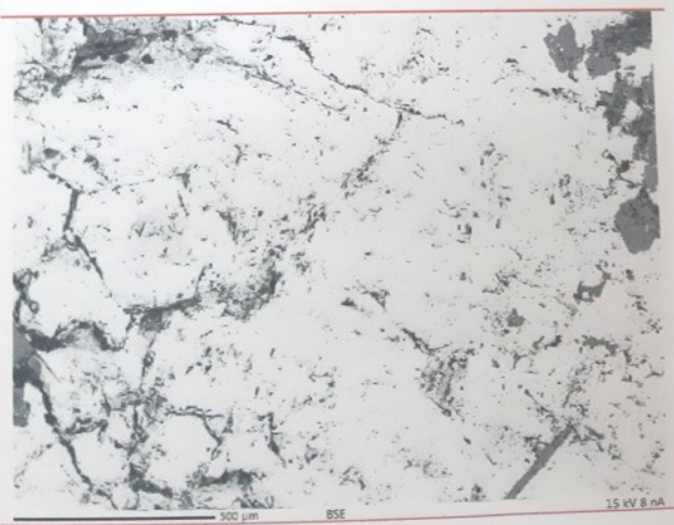

\section{DISCUSSION}

SM is categorized under Maharasa verg by Rasaratnasamucchaya (2). However, the author of Rasatarangini $\left(20^{\text {th }}\right.$ Century) Sri Sadanand Sharma explains SM in Upadhatu verg and gave detail description (10). SM is mineral having peeta verna like Swarna. It is also described as Upadhatu of gold of two types i.e. Swarna Makshika having golden lister and Raupya Makshika having silver luster (11). It has been established by different studies that gold colored SM mineral should be used therapeutically. The present study was aimed to focus the mineralogical characterization of mineral SM according to Grahya Lakshana as explained in Ayurvedic classics as well as the mineralogical standards as mentioned in the Ayurvedic Pharmacopoea of India. The most useful properties for identifying the minerals are color, crystal habit, crystal system, twinning, cleavage, fracture, tenacity, hardness, luster, streak, diaphaneity, specific gravity and fusibility. Some other properties such as reaction with acids, solubility in water, magnetism, taste, odor are helpful in identifying certain minerals (12). The most of the physical properties verified in this study are very well match with the standard of chalcopyrite (9) (Table-2, Figure-1). The properties mentioned in the classical texts such as Swarna Sannibham, Snigdha, Guru, Nishkona, Kalimam Vikirettattu Kare Ghrushtam and rubbing on the stone, are very well matched with crystal habit, luster, nature etc, the physical properties of mineralogy.

$\mathrm{SM}$ is chalcopyrite $\left(\mathrm{CuFeS}_{2}\right)$ is widely spread and common which contains iron $(\mathrm{Fe})$, copper $(\mathrm{Cu})$ and Sulphur (S). It is one of the minerals referred to as "Fool's Gold" because of its bright golden color. It is differentiated from gold which is more buttery yellow, ductile and malleable. Luster describes the appearance of mineral when the light is reflected from its surface. Its metallic luster represents the presence of metal. SM, when rubbed on hand gives black color on hand and when rubbed on stone gives gold color lines on stone. When heated with charcoal, SM fuses to be a black mass without swelling which is strongly magnetic, as felt by a horse-shoe magnet. It is insoluble in $\mathrm{H}_{2} \mathrm{O}$ and
$\mathrm{HCl}$ but soluble in nitric acid, becomes bluish black. On heating in oxygen atmosphere it gives smell of $\mathrm{SO}_{2}$ (Sulphur dioxide) (13). SM (chalcopyrite) is oxidized as exposure to air or water or with slight heating to sulphates of iron and copper.

$$
2 \mathrm{CuFeS}_{2}+7.5 \mathrm{O}_{2} \text { à } 2 \mathrm{CuSO}_{4}+\mathrm{Fe}_{2} \mathrm{O}_{3}+2 \mathrm{SO}_{2}
$$

EMPA analytical techniques has been applied for elemental analysis of SM. The EMPA study confirmed the presence of $\mathrm{Cu}, \mathrm{Fe}$, and $\mathrm{S}$ and formed the structure $\mathrm{CuFeS}_{2}$. The trace elements of $\mathrm{Ni}, \mathrm{Pb}, \mathrm{Sn}, \mathrm{As}, \mathrm{Sb}, \mathrm{Ba}$, $\mathrm{Si}, \mathrm{Al}, \mathrm{Mg}$ and $\mathrm{Na}$ are present in trace amounts. The presence of trace elements may be due to collection of raw material from different places.

Chalcopyrite $\left(\mathrm{CuFeS}_{2}\right)$, brass yellow mineral, occurs in most sulfide mineral deposits throughout the world. It is most important ore of copper for thousands of years. It has a positive vibration that is known to increase happiness, joy and belief in yourself. It is an excellent stone to use in meditation. This stone has an unusual energy that is brought through a strong spiritual, even mystical energy. It helps the universal energies to clear anything that prevents perfect health. It is also used in jewelry (14). The present analytical study confirms the authenticity of SM by following the standards of classical as well as modern methods. However, SM is therapeutically used by preparing. SM Bhasma after proper Shodhana and Marana $(2,3)$ with proper combination of other drugs and dosage form. The classical procedures (Shodhana and Marana) are very effective in converting the macro form/nano range. Thus, the Bhasma are considered as nano medicine and the application of which is one of the emerging trend used in medicine (15).

\section{Conclusion}

Ayurveda, the Indian system of medicine deals with a number of metals and minerals. SM, a chalcopyrite, one such minerals has iron( $\mathrm{Fe})$, copper $(\mathrm{Cu})$ and sulphur(S) as major ingredients along with other trace elements of therapeutic importance. In today's era of science and technology, it is essential that the details about raw metals/minerals by which medicines are prepared, must be explored to the scientific community and regulatory authority for its validation, authentication and future development of Ayurvedic system of medicine. Studies related with characterization of SM are very few. In the present study, efforts has been made to analyse SM through the methods mentioned in Ayurvedic classics as well as modern methods. The study would be helpful in preparing therapeutically active SM Bhasma.

\section{Conflict of Interest:} None

\section{Acknowledgement}

The author is thankful to Prof. N.V. Chalapathi Rao and Dr. Dinesh Pandit, Department of Geology, Centre of Advance Study, Banaras Hindu University, Varanasi for EPMA study of studied sample. 


\section{References}

1. Wadekar MP, Patel RK. Preparation and characterization of a copper based Indian Traditional Drug: Tamra Bhasma. Journal of Pharmaceutical and Biomedical Analysis 2005; 39; 951-955.

2. Govinda Bhagavatpada, Rasa Hridaya Jantrum with Mugdavabodhini, Sanskrit commentary of Chaturbharja Mishra, Edited by Acharya Doulatram, Rasa Shastri, 2 ${ }^{\text {nd }}$ Edn, Varanasi, Choukhamba Publishers, 2001, $3^{\text {rd }}$ Chapter, Verse 3-16, 86-88 p.

3. Acharya Sri Machava, Ayurveda Prakasha, Edited by Gulraj Mishra, Varanasi Choukhamba Bharathi Academy, 1999. $4^{\text {th }}$ Chapter, Verse 1-17, 407-412 p.

4. Agnivesha, Pratisamskarana by Charaka and Drudhabala, Charaka Samhita, hindi translation by Pandit Kashinath Shastry, $6^{\text {th }}$ Edn, Varanasi, Choukhamba Sanskrit Samsthan, 2000, Chikitsa Sthana, $7^{\text {th }}$ Chapter, Verse 71, 72, $211 \mathrm{p}$.

5. Taviad KK, Vekariya S, Bedarkar P, Galib R, Patgiri BJ, Process standardization of Swarna Makshika Shodhana (purification) in Triphala Kwatha (decoction). International Quarterly Journal of Research in Ayurveda 2018, 39, 187-194.

6. Anonymous. Pharmacopoeia of India, Govt. of India, Ministry of Health and Family Welfare, Department of Ayurveda, Yoga and Naturopathy, Unani, Siddha and Homeopathi, New Delhi, Ist Edn., Part 1, Vol VII (minerals and metals), 2008.
7. Rasa Vagbhata, Rasaratnasamucchaya, Edited by Sri Dattatreya Ananta Kulkarni, , New Delhi, Meharchand Lachmandas Publication, Chapter 2/82, 1998.

8. Dattatreyak. Editor, Rasaratnasamucchaya of Acharya Madhava. Chapter 4, verse 81-82, $2^{\text {nd }}$ Edn New Delhi: Meharchand Lachamandas Publication, 2010, p. 29.

9. Available from: https://en.m.wikipedia.org

10. Vagabhatacharya, Rasaratnasamucchaya, Edited by Ambikadatta Shastry, $8^{\text {th }}$ Edn., Varanasi, Choukhamba Amar Bharti Prakashan, 1998, $2^{\text {nd }}$ Chapter, Verse 73-78, 48-50 p.

11. Vraddha Vagbhata Virachita Astanga Sangraha, Indu Vyakhya Samhita, Translated by Vaidya Ayanta Damodar Attavali, Pune, Srimal Atreya Prakashan, 1990, Uttara Tantra, $49^{\text {th }}$ Chapter, Verse 330-340, 938-939 p.

12. Geology Laboratory, Mineral Properties, Available from: https://www.saddleback.edu/faculty/jrepka/ notes/GEOmineralLAB_1.pdf.

13. Shahyoun $C$, Kingman $\bar{S} W$, Rowson NA. The effect of heat treatment on chalcopyrite. Phys. Sep. Sci. Eng. 2003; 12; 23-30.

14. Available from : https://www/healing-cristals.

15. Ajay G, Anil M., Arvind LB. Significance of nanotechnology in medical sciences. Asian J. Pharma. 2008; 2; 80-5. 